Schulich School of Law, Dalhousie University

Schulich Law Scholars

Articles, Book Chapters, \& Blogs

Faculty Scholarship

2007

Canada-USA Bilateral Fisheries Management in the Gulf of Maine:

Under the Radar Screen

David VanderZwaag

Emily J. Pudden

Follow this and additional works at: https://digitalcommons.schulichlaw.dal.ca/scholarly_works

Part of the Environmental Law Commons 


\section{Canada-USA Bilateral Fisheries Management in the Gulf of Maine: Under the Radar Screen}

\section{Emily J. Pudden and David L. VanderZwaag}

Canada and the USA have developed a series of cooperative initiatives that address transboundary fisheries issues in the Gulf of Maine. The CanadaUSA Steering Committee serves as an umbrella forum for discussing and coordinating transboundary management measures. Through the work of the Transboundary Resource Assessment Committee and the Transboundary Management Guidance Committee, the Steering Committee has overseen the development of joint scientific stock assessments and a sharing agreement for groundfish resources in the vicinity of the eastern Georges Bank. The bilateral Fisheries Enforcement Agreement helps ensure the success of such cooperative management initiatives by combating illegal fishing in the vicinity of the international boundary. However, the largely informal 'under the radar screen' arrangements, while positive on many fronts, to date fall short of fully implementing key principles of sustainable development, such as public participation, the ecosystem approach, integration and precaution.

\section{INTRODUCTION}

In the 1970s, Canada and the USA extended their offshore jurisdictions to 200 nautical miles and the Gulf of Maine became the exclusive domain of the Canadian and US fisheries. ${ }^{1}$ Although the two countries periodically exchanged scientific information, their fisheries were managed independently. ${ }^{2}$

\footnotetext{
${ }^{1}$ Fishery Conservation and Management Act of 1976, 16 U.S.C. $\S$ 1801 et seq. (Supp. 1976) established a US 200-mile fishery conservation zone, effective from 1 March 1977; Proposed Fishing Zones of Canada (Zones 4 and 5) Order, P.C. 1977-1, 110 C. Gaz., Extra No 101 (Territorial Sea and Fishing Zone Act of 1964, R.S.C. 1970, c. T-7, am. by R.S.C. 1970 (1st Supp.), c. 45) established Canada's 200-mile fishing zone, effective from 1 January 1977.

${ }^{2}$ Transboundary Management Guidance Committee, Development of a Sharing Allocation Proposal for Transboundary Resources of Cod, Haddock and Yellowtail Flounder on Georges Bank, Fisheries Management Regional Report 2002/01 (Fisheries and Oceans Canada Maritimes Region, 2002), at 3, ('Sharing Proposal'), available at <http://www.mar.dfo-mpo.gc.ca/science/tmgc/background/FMR\%202002_ 01.pdf>.
}

Problems emerged as a result of this management structure. The countries' jurisdictional claims overlapped, in an approximately $30,000 \mathrm{~km}^{2}$ area, at the eastern end of Georges Bank. ${ }^{3}$ The disputed region was home to several commercial groundfish species, including cod, haddock and yellowtail flounder. Although the jurisdictional issue was resolved, in October 1984, when the International Court of Justice (ICJ) established the international boundary between the two countries in the Gulf of Maine, ${ }^{4}$ the problem of managing Georges Bank's transboundary fisheries resources remained.

In the years following the ICJ decision, Canadian and US fishing activities were confined to their respective national jurisdictions and cooperative management was virtually non-existent. ${ }^{5}$ Meanwhile, increased fishing efforts on both sides of the boundary, throughout the 1980 s, led to the over-exploitation of the transboundary groundfish stocks. ${ }^{6}$

In response to this growing problem, Canada and the USA developed a series of cooperative initiatives aimed at addressing transboundary fisheries issues. The Canada-USA Steering Committee was established, in 1995, as an umbrella forum for discussing and coordinating transboundary management measures in the Gulf of Maine. Through the work of its various sub-committees and working groups, the Steering

\footnotetext{
${ }^{3}$ G.J. Herbert, 'Fisheries Relations in the Gulf of Maine: Implications of an Arbitrated Maritime Boundary', 19:4 Marine Pol'y (1995), 301, at 306. Georges Bank is a shallow submarine bank located along the eastern boundary of the Gulf of Maine, between Cape Cod, Massachusetts and the province of Nova Scotia.

${ }^{4}$ ICJ 12 October 1984, Case Concerning Delimitation of the Maritime Boundary in the Gulf of Maine Area (Canada v. USA) [1984] ICJ Rep. 246. However, it should be noted that the ICJ was not asked to resolve the disputed boundary around Machias Seal Island and negotiations between Canada and the USA have, to date, not been successful in forging an agreement on the management of lobster resources in the disputed zone. For a detailed discussion of the ongoing dispute, which is beyond the scope of this article, see T.A. Cheney, Examination of the Lobster Fishery in the Internationally Disputed 'Grey Zone': History, Management and Options, Unpublished Graduate Research Project Paper (Marine Affairs Program, Dalhousie University, 2004).

${ }^{5}$ See Sharing Proposal, n. 2 above, at 3.

${ }^{6}$ Ibid.
} 
Committee has overseen the development of joint scientific stock assessments and a sharing agreement for eastern Georges Bank groundfish, among other schemes. The Fisheries Enforcement Agreement, adopted by Canada and the USA in 1990, helps ensure the success of such cooperative management initiatives by combating illegal fishing in the vicinity of the international boundary.

However, as this article highlights, the largely informal 'under the radar screen' arrangements to date fall short of fully implementing key principles of sustainable development. These principles include public participation, the ecosystem approach, integration and precaution.

\section{BILATERAL FISHERIES MANAGEMENT REGIME}

The Canada-USA Steering Committee is the oversight body that guides transboundary management issues in the Gulf of Maine. ${ }^{7}$ This informal advisory group coordinates bilateral stock assessments and a sharing scheme for transboundary groundfish resources through the actions of the Transboundary Resource Assessment Committee (TRAC) and the Transboundary Management Guidance Committee (TMGC). The Steering Committee supervises additional cooperative transboundary initiatives in the Gulf of Maine via the Canada-USA Integration Committee. The Steering Committee is co-chaired by the Director-General for the Maritime Region, Department of Fisheries and Oceans (DFO) and the Northeast Regional Administrator of the US National Marine Fisheries Service (NMFS) ${ }^{8}$ Committee members also include representatives of the New England Fisheries Management Council (NEFMC), Canada's Gulf of Maine Advisory Committee (GOMAC), and Canadian and US fishing industries. ${ }^{9}$ The Steering Committee meets bi-annually to discuss transboundary

\footnotetext{
${ }^{7}$ Fisheries and Oceans Canada (DFO), Georges Bank Haddock Report (DFO, 2006), at 13-15 ('Haddock Report'). It should be noted that the Steering Committee operates within the context of the broader cooperative relationship existing between Canada and the USA. For example, officials from the Department of Fisheries and Oceans and the National Oceanic and Atmospheric Administration (NOAA) conduct annual informal consultations aimed at improving bilateral communication and coordination on fisheries conservation and management issues, including transboundary stocks in the Gulf of Maine. See Office of International Affairs (OIA), International Agreements Concerning Living Marine Resources of Interest to NOAA Fisheries (National Marine Fisheries Service, NOAA, 2006), at 107, available at <http://www.nmfs.noaa.gov/ocs/mafac/meetings/ 2006_02/docs/05-06\%20International\%20Agreements1.pdf\#search= \%22INTERNATIONAL\%20AGREEMENTS\%20CONCERNING\%20 LIVING\%20MARINE\%20RESOURCES\%20OF\%2OINTEREST\%20 TO\%20NOAA\%20FISHERIES\%20\%22>.

${ }^{8}$ F.G. Peacock and G. Peters, Draft: Canada/USA Regional Transboundary Guidance (unpublished document on file with the authors, undated), at 1 .

${ }^{9}$ Ibid.
}

resource management issues and the cooperative actions necessary to address them. ${ }^{10}$

Under the auspices of the Steering Committee, scientists in Canada and the USA first compiled joint stock assessments for Georges Bank cod, haddock and yellowtail flounder in 1997. The success of this coordinated effort led to the formation of a groundfish TRAC in 1998, which combined stock assessment and peer review processes within the work of a single joint Canada-US committee. ${ }^{11}$ TRAC is co-chaired by representatives from the NMFS and DFO. Since 2000, TRAC has served as the scientific arm of the TMGC. ${ }^{12}$ TRAC members review fishery, survey and biological data to evaluate the status of cod, haddock and yellowtail populations on Georges Bank, and submit annual stock assessments to the TMGC. ${ }^{13}$

The TMGC was established, in 2000, to provide Canadian and US decision makers with non-binding advice on the management of transboundary cod, haddock and yellowtail flounder stocks in an effort to ensure the consistent management of these shared resources. ${ }^{14}$ The group is composed of two government and four fishing industry representatives from each country. ${ }^{15}$ The committee is responsible for developing guidance documents, such as harvest strategies and resourcesharing approaches, for fisheries management authorities in the two countries. ${ }^{16}$

The Steering Committee's TRAC/TMGC framework continues to expand and will soon be applied to other transboundary commercial fish species. A TRAC specific to herring was formed in $2005^{17}$ and work is progressing towards the formation of a related TMGC, possibly by 2008. ${ }^{18}$ A TRAC and TMGC for mackerel have been proposed and may be in place as early as $2008 .{ }^{19}$ The possibility of developing TRACs for halibut, dogfish and pollock has also been discussed. ${ }^{20}$

The most recent organizational development under the framework of the Canada-USA Steering Committee was

\footnotetext{
${ }^{10}$ M. Westhead, Canada/US Steering Committee (22 July 2006)

(unpublished document on file with the authors), at 1.

${ }^{11}$ See Haddock Report, n. 7 above, at 13-14.

12 See M. Westhead, n. 10 above, at 1.

${ }^{13}$ See Haddock Report, n. 7 above, at 14.

${ }^{14}$ For a general overview of the function and structure of the TMGC, see the website available at <http://www.mar.dfo-mpo.gc.ca/science/ tmgc/ introduction.html>

${ }^{15}$ See ibid.; see also M. Westhead, n. 10 above, at 1.

${ }^{16}$ See Transboundary Management Guidance Committee, Guidance Document 2005/01 (Fisheries and Oceans Canada and NOAA Fisheries, 2005), available at <http://www.mar.dfo-mpo.gc.ca/ science/tmgc/publications/GD2005_1_E.pdf> ('Guidance Document 2005/01').

17 See Haddock Report, n. 7 above, at 14.

${ }^{18}$ Email from G. Peacock, Executive Director, Federal/Provincial Relations, DFO Maritimes (5 January 2007) (on file with authors).

${ }^{19}$ See M. Westhead, n. 10 above, at 1.

${ }^{20}$ Ibid.
} 
the approval of the Canada-USA Integration Committee (IC) in September 2005. ${ }^{21}$ The IC serves as the strategic and operational arm of the Steering Committee, to which it reports on a semi-annual basis. ${ }^{22}$ The IC will also provide a direct link to the TMGCs and the various working groups that operate under the umbrella of the Steering Committee. ${ }^{23}$ The Species at Risk Working Group, Habitat Working Group and Oceans Working Group will report directly to the IC. IC membership will be equally divided between Canada and the USA, with the Canadian and US co-chairs selecting ad hoc members from the TMGCs and working groups, to join the four core members, on an issue-by-issue basis. ${ }^{24}$ The IC's mandate, as authorized by the Steering Committee, is to assist in the integration of policies and ensure consistency in approach across the TMGCs and working groups. As part of this process, the IC will provide recommendations to, and undertake record keeping, archival, coordination and general secretariat services for, the Steering Committee, TMGCs and working groups. ${ }^{25}$

\section{SHARING ALLOCATION FORMULA FOR GULF OF MAINE GROUNDFISH}

One of the first tasks undertaken by the groundfish TMGC was the development of a resource-sharing formula for allocating eastern Georges Bank cod, haddock and yellowtail flounder stocks between the USA and Canada. The Committee's Sharing Allocation Proposal recommends a common fishing mortalitybased US-Canadian harvest strategy for groundfish resources in a management area corresponding to the fishing unit areas $5 \mathrm{Zj}$ and $5 \mathrm{Zm}$ (5Zjm) for cod and haddock stocks and unit areas 5Zhjmn for yellowtail flounder (see figure 1). ${ }^{26}$ The report provides recommendations for determining resource distribution patterns within this management area and sets out a transitional schedule for proportionally allocating the stocks between the two countries.

\footnotetext{
${ }^{21}$ F.G. Peacock and G. Peters, Bilateral Management of Transboundary Fish Stocks: An Informal Approach to Ecosystem-Based Management, paper presented at the Sharing the Fish - Allocation Issues in Fisheries Management 2006 Conference, Fremantle, Australia, March 2006, available at <http://www.fishallocation.com/assets/pdf/papers/ GregPeacock.pdf>; see also M. Westhead, n. 10 above, at 4.

${ }^{22}$ See M. Westhead, ibid.

${ }^{23}$ Ibid., at 3-4.

${ }^{24} \mathrm{Ibid}$.

${ }^{25}$ See Haddock Report, n. 7 above, at 14-15.

${ }^{26}$ See Sharing Proposal, n. 2 above. Fisheries and Oceans Canada's management area 5Zjm corresponds with the US NMFS's statistical fisheries units 551, 552, 561 and 562. Canadian unit area 5Zhjmn corresponds with US units 522, 551, 552, 561, 562 and 525 (see figure 1).
}

@ 2007 The Authors. Journal compilation (c 2007 Blackwell Publishing Ltd

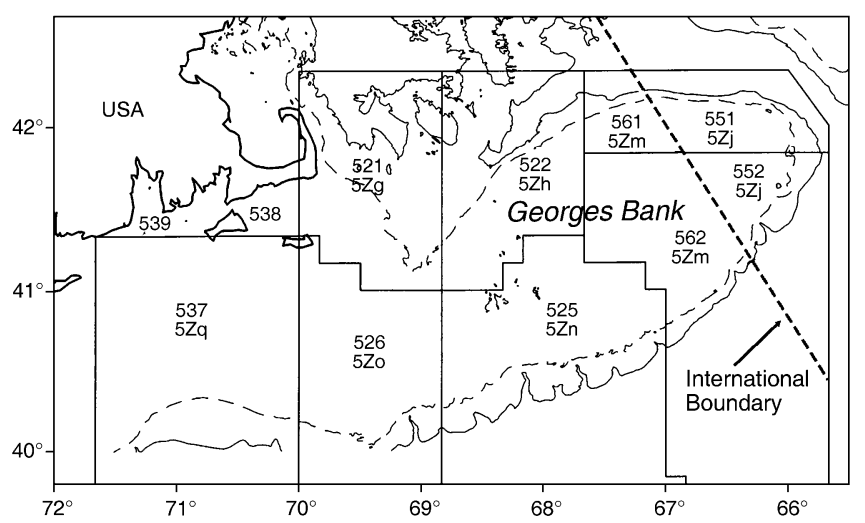

FIGURE 1 GEORGES BANK FISHERIES MANAGEMENT UNITS ${ }^{27}$

The Sharing Allocation Proposal represents a compromise between the disparate sharing proposals initially suggested on behalf of Canada and the USA. Both countries conceded that the sharing agreement should allocate groundfish stocks using a weighted formula based on resource distribution patterns and past fisheries landings. Canada favoured a greater emphasis on resource distribution, to which it assigned a proposed weighting of $95 \%$, with historical utilization to be weighted at $5 \%$. The USA, on the other hand, argued that equal emphasis should be placed on resource distribution and past fisheries landings. ${ }^{28}$

The two countries eventually reached consensus on a number of issues necessary for the development of the resource-sharing formula. DFO fishing unit area $5 \mathrm{Zjm}$ was agreed upon as the management unit for the transboundary cod and haddock stocks. The parties agreed that groundfish resource distribution patterns would be calculated using data collected during the three NMFS and DFO surveys carried out each year. A compromise was also reached with regard to the time period on which historical resource utilization patterns would be based. The years 1967-1994 were selected in order to exclude landings data from the period following the collapse of the Georges Bank cod and haddock stocks. Finally, the decision was made to develop a fixed 7-year transitional schedule for implementing the sharing agreement. ${ }^{29}$

The TMGC Sharing Formula incorporates a 7-year transitional schedule with allocation percentages that take into account both contemporary resource distribution and historical utilization patterns (see box 1 below). The TMGC's proposed method for determining the proportion of groundfish stocks on either side of the international boundary is designed to take into account changes in resource distribution over time. The committee recommended that distribution patterns be

\footnotetext{
${ }^{27}$ This is adapted from ibid., at 9 .

${ }^{28}$ Ibid., at 38-44.

${ }^{29}$ lbid., at 6.
} 


\section{BOX 1 RESOURCE-SHARING ALLOCATION FORMULA}

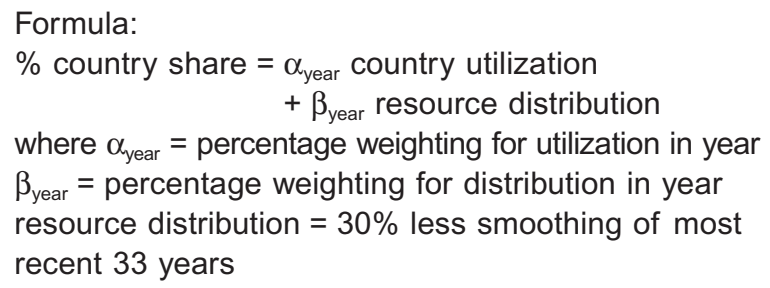

$\begin{array}{lll} & \text { USA } & \text { Canada } \\ \text { Cod } & 40 \% & 60 \% \\ \text { Haddock } & 45 \% & 55 \% \\ \text { Yellowtail } & 98 \% & 2 \%\end{array}$

Percentage weighting (resource distribution/historical landings):

20032004200520062007200820092010

60/40 60/40 65/35 70/30 75/25 80/20 85/15 90/10

calculated annually, using the results of the NMFS's spring and autumn bottom trawl surveys and DFO's annual winter survey for the most recent 33 years. For estimating yellowtail flounder distributions, a simple average of the three surveys conducted each year is employed, since this species does not exhibit marked migration patterns. For cod and haddock, which migrate seasonally, the TMGC proposed classifying the surveys according to the time of year in which they were conducted, to produce average distributions for both the colder winter-spring half of the year and the warmer summer-autumn half. These two seasonal distribution averages are then combined to produce a yearly average. Finally, a statistical smoothing procedure is applied to the averaged survey results to compensate for any anomalies produced by statistical sampling variation or natural, but unpredictable, fluctuations in resource distribution. The resultant figure should represent a reliable near-term (1-3 years) estimate of stock distributions, on either side of the Canada-USA maritime boundary, within the management area. ${ }^{30}$ The historical utilization percentages used in the sharing allocation formula are fixed values that have been calculated based on fishery landings data from the Canadian and US fisheries for the years 1967-1994. ${ }^{31}$

In the first year of the agreement, 2003, the sharing formula assigned a weighting of $60 \%$ to resource distribution and $40 \%$ to historic utilization. This weighting ratio gradually shifts over the course of the 7-year transition period until resource distribution is weighted at $90 \%$ and historical landings at $10 \%$ by $2010 .{ }^{32}$

\footnotetext{
${ }^{30}$ The report recommends the application of a robust locally weighted regression scatterplot smoother. See ibid., at 50-51.

${ }^{31}$ Ibid., at 57.

${ }^{32}$ Ibid.

๑) 2007 The Authors. Journal compilation ๔ 2007 Blackwell Publishing Ltd.
}

\section{TMGC GUIDANCE DOCUMENTS}

Each year, the TMGC publishes a Guidance Document containing a summary of its recommendations to US and Canadian fisheries management authorities. ${ }^{33}$ The reports set out the resource allocation percentages to be applied by each country in drafting their respective fisheries management plans for the coming year. Combined Canada-US Total Allowable Catch (TACs) levels are suggested for eastern Georges Bank cod, haddock and yellowtail flounder resources based on the annual stock assessments compiled by TRAC. The TMGC then applies the sharing allocation formula to allocate proportionally each combined TAC between the two countries' fisheries. In addition to recommending national quotas for the three groundfish species, the Guidance Documents provide information on past exploitation of these fisheries, the state of the resources in terms of biomass indices, species productivity levels and catch risk assessments for the coming fishing year. ${ }^{34}$

\section{DOMESTIC IMPLEMENTATION OF THE SHARING ALLOCATION AGREEMENT}

Although TRAC and the TMGC are international in scope, the fisheries management recommendations developed through these processes must be implemented domestically. Canada and the USA continue to develop and execute separate fisheries management plans. In 2003, Canada and the USA formally agreed to apply the TMGC's resource-sharing allocation formula for Georges Bank cod, haddock and yellowtail flounder to their Gulf of Maine fisheries management plans. ${ }^{35}$

In Canada, authority over the fisheries is centralized under the DFO. GOMAC was established by DFO in 1984 to serve as a government-industry forum for discussing the management of fish stocks in the Gulf of Maine. ${ }^{36}$ GOMAC is co-chaired by the DirectorGeneral of the Scotia-Fundy Region of DFO and a senior member of the fishing industry. ${ }^{37}$ Committee membership includes representatives from DFO, the Atlantic provincial governments, the fishing industry, the Department of Foreign Affairs and International Trade, and the Canadian Consul in Boston. GOMAC provides

\footnotetext{
${ }^{33}$ Guidance Documents for the years 2003-2006 are available on the TMGC website, available at <http://www.mar.dfo-mpo.gc.ca/science/ tmgc/tgd.html>.

${ }^{34}$ See, e.g., Guidance Document 2005/01, n. 16 above.

${ }^{35}$ See Haddock Report, n. 7 above, at 14.

${ }^{36}$ Ibid., at 13.

${ }^{37}$ For a general overview of the function and structure of GOMAC, see the website available at <http://www.mar.dfo-mpo.gc.ca/e/ovrvu.htm>.
} 
DFO with consensus-based advice on transboundary fisheries issues in the Gulf of Maine, including operational, technical and scientific analyses. ${ }^{38}$ The committee liaises with the TMGC, reviews stock status and management assessments and recommends harvest strategies for Gulf of Maine groundfish stocks to the Minister of Fisheries and Oceans. ${ }^{39}$

NEFMC is responsible for managing US fisheries in the Gulf of Maine region. The council is composed of 18 voting members, which include representatives from the NMFS, regional State governments and nominated knowledgeable private individuals (usually fishermen). ${ }^{40}$ A further four non-voting members, representing the US Coast Guard, the Atlantic States Marine Fisheries Commission, the US Fish and Wildlife Service and the State Department, also participate. ${ }^{41}$ The NEFMC's North-East Multi-Species Fisheries Management Plan outlines the management measures in place for a variety of commercial finfish, including Georges Bank cod, haddock and yellowtail flounder. ${ }^{42}$ The TMGC submits its annual TAC recommendations to the NEFMC, for the council's consideration in the development of management strategies for the fisheries under its jurisdiction.

\section{ENFORCING FISHERIES MANAGEMENT MEASURES}

The success of any fisheries regime is dependent upon the level of participant adherence to management measures. Non-compliance with fisheries regulations has been cited as a contributing factor in the overexploitation of fish stocks on Georges Bank. ${ }^{43}$ In the years following the Gulf of Maine boundary delineation, numerous incidents of US vessels illegally fishing in Canadian waters were recorded ${ }^{44}$ Canadian authorities faced a number of difficulties in enforcement near the international boundary. To be prosecuted in Canada, vessels fishing illegally had to first be apprehended. By

\footnotetext{
${ }^{38}$ Ibid.

${ }^{39}$ See Haddock Report, n. 7 above, at 14.

${ }^{40}$ For a general overview of the function and structure of the NEFMC, see the website available at <http://www.nefmc.org/about/index.html>. See also P. Hoagland et al., Marine Area Governance and Management in the Gulf of Maine: A Case Study (Marine Policy Center, Woods Hole Oceanographic Institution, 1996), at 14, available at <http:// www.whoi.edu/cms/files/jblythe/2005/12/Gulf_of_Maine_Final_Report_ (Aug_1996)_\%5Bno_appendices\%5D_6405.pdf\#search=\%22gulf\% 20 of $\% 20$ maine $\% 20$ a $\% 20$ case $\% 20$ study $\% 2$ hoagland $\% 22$ >.

${ }^{41}$ See NEFMC website, ibid.

${ }^{42}$ New England Fisheries Management Council, Fishery Management Plan, Environmental Impact Statement, Regulatory Impact Review and Initial Regulatory Flexibility Analysis for the Northeast Multi-Species Fishery (NEFMC, August 1985), available at <http://www.nefmc.org/ nemulti/index.html> ('Fishery Management Plan').

${ }^{43}$ See P. Hoagland et al., n. 40 above.

${ }^{44}$ See G.J. Herbert, n. 3 above, at 301.

staying near the boundary line, fishers were often able to escape back across the border when a Canadian patrol vessel was spotted. Even if charges happened to be brought in the USA, the potential penalties under US legislation were fairly insignificant in comparison with the harsher Canadian laws. Canadian penalties included CAN $\$ 100,000$ fines, confiscation of catch, impoundment of vessel and possible jail sentences. In comparison, the maximum US $\$ 10,000$ fine, under the US Lacey Act, ${ }^{45}$ could be treated as a justifiable business expense. ${ }^{46}$

\section{FISHERIES ENFORCEMENT AGREEMENT}

In an effort to address the problem of illegal fishing, Canada and the USA signed a reciprocal Fisheries Enforcement Agreement in September 1990. ${ }^{47}$ The agreement obliges each country to enact domestic prohibitions making it illegal for its nationals to violate the fisheries laws and regulations of the other State while within the jurisdiction of that country. ${ }^{48}$ As a result, boundary violators fishing illegally in one country's waters now violate the laws of both countries. The parties also committed to consultations with each other regarding the implementation of the agreement, including the effectiveness of penalties and fisheries enforcement practices to be carried out in the vicinity of the maritime boundary. ${ }^{49}$ Finally, the agreement obliges Canada and the USA to make an effort to inform their nationals, who fish in the vicinity of the boundary, as to the law-enforcement practices of the other party. ${ }^{50}$

\section{IMPLEMENTING COOPERATIVE ENFORCEMENT MEASURES}

Following the signing of the Fisheries Enforcement Agreement, Canada and the USA implemented the agreement through domestic laws, making it an offence for non-authorized fishing in the other's waters and providing for consistent penalties. ${ }^{51}$ The maximum penalties for boundary violations have also been synchronized to reflect the previous Canadian standards. In addition, the two countries have held regular

\footnotetext{
${ }^{45}$ Lacey Act Amendments of 1981, 16 U.S.C. §§ 3371-3378 (1982).

${ }^{46}$ See G.J. Herbert, n. 3 above, at 314.

${ }^{47}$ Agreement between the Government of Canada and the Government of the United States of America on Fisheries Enforcement (Ottawa, 26 September 1990).

${ }^{48} \mathrm{Ibid}$., Article I.

${ }^{49}$ lbid., Article II.

${ }^{50} \mathrm{Ibid}$.

${ }^{51}$ The USA has implemented the agreement by issuing the International Fisheries Regulations, USA-Canada Fisheries Enforcement, 50 C.F.R. §§ 300.140-300.144; Canada implemented the agreement with the USA Waters Fisheries Regulations, SOR/ 91-660, revoked and subsumed by United States Waters Fisheries Regulations, revocation Fishery (General) Regulations, amendment, SOR/94-296.
} 
implementation meetings to review enforcement practices and discuss the development of cooperative standards, policies and strategies. Among the subjects that have been addressed are prosecution practices, evidentiary requirements, notification procedures, the interpretation of regulations and hot pursuit. ${ }^{52}$ Canada and the USA regularly cooperate in patrolling the areas on either side of the Gulf of Maine boundary to deter illegal fishing activities and monitor compliance with applicable regulations. Fisheries surveillance operations take the form of sea patrols, including onboard inspections of fishing vessels, and aerial overflights. A more recent technique for monitoring vessel catch locations is the use of vessel monitoring systems (VMS), which apply satellite technology to monitor harvesting operations electronically. ${ }^{53}$ To help ensure a coordinated approach to fisheries enforcement on both sides of the border, the NMFS Office for Law Enforcement meets regularly with its counterparts in DFO to exchange enforcement information. Data-sharing is also facilitated by both countries' memberships in the International Network for the Cooperation and Coordination of Fisheries-Related Monitoring Control and Surveillance Activities ('MCS Network'). ${ }^{54}$

\section{EFFECT OF COOPERATIVE ENFORCEMENT AND MANAGEMENT ON BOUNDARY VIOLATIONS}

DFO records detailing the incidence of boundary violations in the Gulf of Maine from 1988 to 2006 demonstrate the positive effect of the Fisheries Enforcement Agreement, and the cooperative fisheries management measures implemented by Canada and the USA, in reducing illegal fishing. Violation numbers, which had been on the rise in the years following the maritime boundary delineation, peaked in $1989 .{ }^{55}$ Increased levels of cross-border cooperation, coinciding with the signing of the Enforcement Agreement, contributed to the substantial drop in recorded incidents of illegal fishing from $1990 .{ }^{56} \mathrm{~A}$ further decrease in boundary violation numbers occurred from 1994, following the two countries' joint commitment to reduce fishing levels and rebuild stocks in the Gulf of Maine. ${ }^{57}$

Boundary violations by US scallopers declined when the NEFMC closed large areas of the US portion of

\footnotetext{
${ }^{52}$ See OIA, n. 7 above, at 109-110.

53 J.K. Randall, 'Improving Compliance in US Federal Fisheries: An Enforcement Agency Perspective', 35:4 Ocean Devel. \& Int'l L. (2004), 287.

${ }^{54}$ See OIA, n. 7 above, at 110.

${ }^{55}$ Fisheries and Oceans Canada (DFO), USA Transboundary Violations Canada/USA Boundary Line (unpublished document on file with DFO, undated) ('Transboundary Violations').

${ }^{56}$ See G.J. Herbert, n. 3 above, at 315.

${ }^{57}$ See Transboundary Violations, n. 55 above.

Georges Bank to multi-species fishing activities, in December 1994, in an effort to restore declining groundfish populations. ${ }^{58}$ Among the closed zones was a section bordering a significant length of the Gulf of Maine boundary, designated as Closed Area II. Since June 1999, the southern part of this closed area has been re-opened, as a controlled access area, to allow limited scallop harvesting operations to take place. ${ }^{59}$ Fishing activities within this area have been closely monitored, however, through the use of surveillance patrols, on-board observers and the electronic reporting of catches. ${ }^{60}$ There has been no recorded increase in illegal transboundary fishing in this region since the limited re-opening. ${ }^{61}$ This management regime has likely helped reduce the number of boundary violations committed by US scallop vessels on Georges Bank. ${ }^{62}$

Boundary violations by groundfish fishers were less of a problem in the years preceding the Enforcement Agreement, as these stocks were in decline on both sides of the border. In such cases, the risk of being caught did not justify potential rewards from fishing illegally. ${ }^{63} \mathrm{In}$ addition, Closed Area II, on the US side of the Gulf of Maine boundary line, has continued to remain closed to groundfish fishing operations. The cooperative management of groundfish resources by Canada and the USA, through the Sharing Allocation Agreement, is also seen as an important factor in the prevention of current and future boundary violations by groundfish fishing vessels. ${ }^{64}$

\section{ASSESSMENT OF TRANSBOUNDARY COOPERATION}

The forging of informal cooperative fisheries management arrangements for the Gulf of Maine region is positive on many fronts. The arrangements have established 'good neighbourly relations' in place of previous conflicts and tensions over the allocation of shared groundfish

\footnotetext{
${ }^{58}$ D. Hart, Status of Fishery Resources off the Northeastern United States: Sea Scallops (Northeast Fisheries Science Center (NEFSC), National Marine Fisheries Service, 2001), available at <http:// www.nefsc.noaa.gov/sos/spsyn/ iv/scallop/>.

${ }^{59}$ New England Fisheries Management Council, Framework Adjustment 18 to the Atlantic Sea Scallop FMP: Including an Environmental Assessment, Regulatory Impact Review, Regulatory Flexibility Analysis and Stock Assessment and Fishery Evaluation (SAFE) Report (NEFMC, 2005), at 3-1, available at <http://www.nefmc.org/ scallops/> ('Framework Adjustment 18').

${ }^{60}$ See D. Hart, n. 58 above.

${ }^{61}$ Fisheries and Oceans Canada (DFO), Canada/USA Enforcement Treaty - Since 1991: Vessel Occurrences - Canada/USA Boundary - Atlantic Coast (database maintained by Conservation and Protection Branch, DFO Maritimes).

62 Personal communication with G. Peacock, Executive Director, Federal/Provincial Relations, DFO Maritimes (19 July 2006).

${ }^{63}$ See G.J. Herbert, n. 3 above, at 312.

${ }^{64}$ See personal communication with G. Peacock, n. 62 above.
} 
stocks. ${ }^{65}$ While international law in relation to equitable sharing of transboundary resources is still limited, ${ }^{66}$ with equity being an open-textured concept subject to varying interpretations,${ }^{67}$ Canadian and US officials have been able to reach a creative allocation accommodation, with geographical distribution of the groundfish stock being phased in as the increasingly dominant factor. The shift from historical catch emphasis to the geographical distribution of fish stocks in national waters could be exemplary to other States of how equitable sharing might be approached. The two countries can be viewed as marching in step with the 1982 United Nations Convention on the Law of the $\mathrm{Sea}^{68}$ and its mandate that where fish stocks are shared across exclusive economic zones, countries are required to seek directly or through sub-regional or regional organizations to agree upon necessary measures to conserve and develop shared stocks. ${ }^{69}$ Scientific and bureaucratic cooperation has been achieved without high costs of administration and formalized structures. ${ }^{70}$ Federal officials took on a difficult task that was beyond the mandate and competence of the Gulf of Maine Council on the Marine Environment established in $1989 .^{71}$

However, various aspects of the bilateral 'under the radar' arrangements may be characterized as falling

\footnotetext{
${ }^{65}$ For reviews of the rocky relations over fisheries including a failure to adopt a negotiated 1979 East Coast Fisheries Agreement, see D.L. VanderZwaag, The Fish Feud: The US and Canadian Boundary Dispute (Lexington Books, 1983); L.J. Prelli and M. Larsen-Becker, 'Learning from the Limits of an Adjudicatory Strategy for Resolving United States-Canada Fisheries Conflicts: Lessons from the Gulf of Maine', 41:2 Nat. Resources J. (2001), 445.

${ }^{66}$ While the equitable utilization principle has been quite well developed in international watercourse law, the meaning of equitable sharing in other transboundary resource areas, such as hydrocarbon and mineral deposits, clean air, fisheries and endangered species is less clear. See, e.g., P.G. Cameron, 'The Rules of Engagement: Developing CrossBorder Petroleum Deposits in the North Sea and the Caribbean', 55:3 ICLQ (2006), 559; S.C. McCaffrey, 'Book Review of "Sharing Transboundary Resources: International Law and Optimal Resource Use" by Eyal Benvenisti', 17:3 Emory Int'l L. Rev. (2003), 1091; and R.E. Hall, 'Transboundary Groundwater Management: Opportunities under Law for Groundwater Management in the United States-Mexico Border Region', 21:3 Ariz. J. Int'l \& Comp. L. (2004), 873.

${ }^{67}$ For six of the most common conceptions of fairness and equity, see P.G. Harris, 'The European Union and Environmental Change: Sharing the Burdens of Global Warming', 17:2 Colo. J. Int'l Envtl L. \& Pol'y (2006), 309.

${ }^{68}$ United Nations Convention on the Law of the Sea (Montego Bay, 10 December 1982).

${ }^{69}$ Ibid., Article 63(1) (emphasis added).

${ }^{70}$ See personal communication with G. Peacock , n. 62 above.

${ }^{71}$ The Governors of Maine, Massachusetts and New Hampshire and Premiers of New Brunswick and Nova Scotia signed the Agreement on Conservation of the Marine Environment of the Gulf of Maine between the Governments of the Bordering States and Provinces in 1989, printed in Gulf of Maine Council on the Marine Environment, The Gulf of Maine Action Plan 1991-2000 (GoMCME, 1991), Appendix. State and provincial leaders reaffirmed their commitment to the wise management of the Gulf of Maine and its watershed in the Gulf of Maine Council's Action Plan 2001-2006: Gulf of Maine Council on the Marine Environment, Action Plan 2001-2006 (GoMCME, 2002), at 6.
}

short of modernization trends in ocean governance driven by sustainable development principles, ${ }^{72}$ in particular public participation, the ecosystem approach, integration and precaution. Perhaps the greatest criticism is the 'closed club' approach, whereby industry and government representatives, supported with scientific advice, have controlled fisheries management recommendations. The Food and Agriculture Organization (FAO) Code of Conduct for Responsible Fisheries, ${ }^{73}$ meant to guide both national and regional fisheries management approaches, ${ }^{74}$ urges States to broaden participation to include environmental and other interested organizations. ${ }^{75}$

The informal arrangements also appear to fall short of implementing the ecosystem approach, ${ }^{76}$ sometimes equated with ecosystem-based management. ${ }^{77}$ While the ecosystem approach is still an evolving concept ${ }^{78}$ and brims with various uncertainties ${ }^{79}$ the approach does suggest some fundamental fisheries management shifts that have not yet been fully embraced under the informal USA-Canada cooperative arrangements. Those shifts include considering fish harvesting impacts on associated species and marine biodiversity ${ }^{80}$ and subjecting proposed commercial scale fisheries to ecological impact assessments. ${ }^{81}$ Canadian and US fisheries

\footnotetext{
${ }^{72}$ See D.R. Rothwell and D.L. VanderZwaag, 'The Sea Change Towards Principled Oceans Governance', in D.R. Rothwell and D.L. VanderZwaag (eds), Towards Principled Oceans Governance: Australian and Canadian Approaches and Challenges (Routledge, 2006), 3. See also, D.R. Christie, 'It Don't Come EEZ: The Failure and Future of Coastal State Fisheries Management', 14:1 J. Transnat'l. L. \& Pol'y (2004), 1.

${ }^{73}$ Food and Agriculture Organization, Code of Conduct for Responsible Fisheries (FAO, 1995) ('FAO Code').

${ }^{74}$ Ibid., Article 2.

${ }^{75}$ Ibid., Article 7.1.6.

${ }^{76}$ See FAO Fisheries Department, The Ecosystem Approach to Fisheries, FAO Technical Guidelines for Responsible Fisheries No 4, Suppl. 2 (FAO, 2003); Food and Agriculture Organization, Putting into Practice the Ecosystem Approach To Fisheries (FAO, 2005).

${ }^{77}$ For a review of ecosystem-based management, see S.J. Hall and B. Bainprize, 'Towards Ecosystem-Based Management', 5:1 Fish and Fisheries (2004), 1. The FAO has preferred the term 'ecosystem approach' to be consistent with use of the term 'precautionary approach' and to ensure fisheries objectives are given due weight. See S.M. Garcia et al., The Ecosystem Approach to Fisheries: Issues, Terminology, Principles, Institutional Foundations, Implementation and Outlook, FAO Fisheries Technical Paper No 443 (FAO, 2003), at 6. ${ }^{78}$ For recent international discussions on the ecosystem approach, see Report on the Work of the United Nations Open-Ended Informal Consultative Process on Oceans and Law of the Sea at its Seventh Meeting (UN Doc. A/61/156, 17 July 2006), available at <http:// www.un.org/Depts/los/consultative_process/consultative_process. htm\#A/61/156>.

${ }^{79}$ See D.R. Rothwell and D.L. VanderZwaag, n. 72 above, at 6.

${ }^{80}$ FAO Fisheries Department, n. 76 above, at 13.

${ }^{81}$ See D.R. Rothwell and D.L. VanderZwaag, n. 72 above. The scope of the called-for environmental impact assessment may be subject to debate in light of the FAO Code of Conduct's recommendation that prior impact assessment be undertaken before a new fishery is developed or a new technology is deployed (Articles 8.4.7 and 12.11). See FAO Fisheries Department, n. 76 above, at 82.
} 
managers have followed a 'sectoral fixation' of recommending catch allocations for three target groundfish species. Single-stock assessments, rather than consideration of ecosystem inter-relationships, have been the norm. ${ }^{82}$

However, aspects of the ecosystem approach have been adopted or are in the process of adoption in national management systems. ${ }^{83}$ For example, the USA does subject proposed fisheries management plans to environmental impact assessment $;{ }^{84}$ while Canada, through its National Oceans Strategy ${ }^{85}$ calls for implementation of the ecosystem approach where maintaining ecological integrity and health are overall goals. ${ }^{86}$

The over-arching Canada-USA Steering Committee framework has the potential to guide the TRAC and TMGC processes towards broader ecosystem considerations. Working Groups on Endangered Species and Marine Habitat, which feed advice into the CanadaUSA Integration Committee, hold promise, but it remains to be seen how fisheries interests and marine biodiversity values are handled in practice.

Placing fisheries management within an integrated planning framework, also urged by the FAO Code of Conduct ${ }^{87}$ remains an unmet goal for the Gulf of Maine. A fragmented array of transboundary cooperative initiatives and arrangements exist..$^{88}$ The most central cooperative arrangement, the Gulf of Maine Council on the Marine Environment, has largely supported cooperative projects, meetings and workshops, but has not played an integrated planning role and has distanced itself from fisheries management issues. ${ }^{89}$ Recent establishment by the Conference of New England Governors and Eastern Canadian Premiers of an Oceans Working Committee may hold some

\footnotetext{
${ }^{82}$ See Transboundary Management Guidance Committee, Guidance Document 2006/01 (Fisheries and Oceans Canada and NOAA Fisheries, 2006), available at <http://www.mar.dfo-mpo.gc.ca/science/ tmgc/publications/GD2006_1_E.pdf> ('Guidance Document 2006/01'). ${ }^{83}$ For reports on Canadian and US initiatives, see G. Jamieson and C-I. Zhang (eds), Report of the Study Group on Ecosystem-Based Management Science and its Application to the North Pacific, PICES Scientific Report No 29 (North Pacific Marine Science Organization (PICES), 2005).

${ }^{84}$ See Fishery Management Plan, n. 42 above; Framework Adjustment 18, n. 59 above.

${ }^{85}$ Fisheries and Oceans Canada (DFO), Canada's Oceans Strategy: Our Oceans, Our Future (DFO, 2002).

${ }^{86} \mathrm{lbid}$., at 4 and 12.

${ }^{87}$ FAO Code, n. 73 above, Article 10.

${ }^{88}$ See ACZISC Secretariat and Marine and Environmental Law Institute, Dalhousie University, Overview of Current Governance in the Bay of Fundy/Gulf of Maine: Transboundary Collaborative Arrangements and Initiatives, Report prepared for Fisheries and Oceans Canada (2006), forthcoming at <http://www.dal.ca/law/melaw>.

${ }^{89}$ See D.L. VanderZwaag, 'Transboundary Challenges and Cooperation in the Gulf of Maine Region: Riding a Restless Sea Toward Misty Shores', in H.N. Scheiber (ed.), Law of the Sea: The Common Heritage and Emerging Challenges (Martinus Nijhoff, 2000), 265, at 277.
}

integration promise, but the initiative could also add another layer of complexity. ${ }^{90}$

The Canada-USA Integration Committee, although its name may suggest an integrative planning function, does not include key 'players'. Local governments, indigenous groups and non-governmental organizations are not participants. Participation by provincial/State officials is not ensured.

While Section 31 of Canada's Oceans Act ${ }^{91}$ requires the Minister of Fisheries and Oceans to lead and facilitate the development and implementation of integrated management plans for all activities in or affecting Canada's estuaries, coastal waters and marine waters, planning efforts to date have focused on marine areas within Canada. ${ }^{92}$ The initial five large ocean management areas selected for integrated planning implementation do not include transboundary mandates. ${ }^{93}$

Application of the precautionary approach within the informal bilateral cooperative arrangements has also not been explicit. ${ }^{94}$ With no over-arching bilateral fisheries management or regional ocean governance agreement in place, principles for cooperative management and practical implementation implications have not been fleshed out. ${ }^{95}$

The TMGC's Guidance Documents, although at times supporting risk-adverse groundfish quotas, have also advocated, on occasion, risk-neutral and above TACs. For example, in its 2006 Guidance Document for the 2007 fishing year, the TMGC recommended a TAC for

\footnotetext{
${ }^{90}$ Pursuant to Resolution 29-3, adopted at the Twenty-Ninth Annual Conference of the New England Governors and Eastern Canadian Premiers in 2005, the committee is to facilitate the exchange of information, cooperate on marine research and development initiatives, and address environmental and management issues. See New England Governors' Conference, Inc. (NEGC), XVIII:2 NEGC Update (September 2005), at 3.

${ }^{91}$ Oceans Act S.C. 1996, c. 31.

${ }^{92}$ See Fisheries and Oceans Canada (DFO), Policy and Operational Framework for Integrated Management of Estuarine, Coastal and Marine Environments in Canada (DFO, 2002).

${ }_{93}$ The five priority areas include Placentia Bay and the Grand Banks, the Scotian Shelf, the Gulf of St Lawrence, the Beaufort Sea and the Pacific North Coast. See Fisheries and Oceans Canada (DFO), Canada's Oceans Action Plan: For Present and Future Generations (DFO, 2005), at 13-15.

${ }^{94}$ For overviews of the precautionary principle/approach, see $\mathrm{S}$. Marr, The Precautionary Principle in the Law of the Sea: Modern Decision Making in International Law (Brill, 2003); and D. Freestone and E. Hey (eds), The Precautionary Principle in International Law: The Challenge of Implementation (Kluwer Law International, 1996). ${ }^{95}$ For reviews of how national systems have approached precaution, see M. Territo, 'The Precautionary Principle in Marine Fisheries Conservation and the US Sustainable Fisheries Act of 1996', 24:4 Vt. L. Rev. (2000), 1351 and D.L. VanderZwaag et al., 'Canada and the Precautionary Principle/Approach in Ocean and Coastal Management: Wading and Wandering in Tricky Currents', 34:1 Ottawa L. Rev. (2002-2003), 117. For an overview of approaches to fisheries management, including the precautionary approach, see H.N. Scheiber, 'Ocean Governance and the Marine Fisheries Crisis: Two Decades of Innovation - and Frustration', 20:1 Va. Envtl. L.J. (2001), 119.
} 
eastern Georges Bank cod of 1900 metric tonnes (mt) to be risk adverse to exceeding the fishing mortality level agreed upon. ${ }^{96}$ For eastern Georges Bank haddock, a riskneutral approach was followed whereby a $19,000 \mathrm{mt}$ TAC was recommended with a $50 \%$ chance of exceeding the fishing mortality reference agreed to. ${ }^{97}$ The combined Canada/USA Georges Bank yellowtail flounder TAC was recommended to be $1500 \mathrm{mt}$, slightly above a risk-neutral level..$^{98}$

\section{CONCLUSION}

While Canada and the USA have made substantial strides through informal bilateral fisheries arrangements for the Gulf of Maine region, putting integrated transboundary ecosystem management into practice still seems a distant goal. Canada and the USA, while being advanced industrialized States with major scientific and organizational capacities, in many ways are lagging behind other regions of the globe in modernizing and formalizing transboundary ocean relations. ${ }^{99}$ Like the Gulf of Maine Council on the Marine Environment, the informal fisheries arrangements might be described as nascent. ${ }^{100}$

Reaching an integrated ocean governance system for the Gulf of Maine may require all arrangements to be viewable on a 'unified radar screen'. Formalizing the existing array of fragmented cooperative arrangements under a comprehensive regional agreement umbrella is one navigational option with various routes possible. ${ }^{101}$

\footnotetext{
${ }^{96}$ Guidance Document 2006/01, n. 82 above, at 1, followed a fishery mortality limit reference (Fref) of 0.18 . A fishing mortality reference point is an estimated value, derived from an agreed scientific procedure/ model, which provides a benchmark for analysing the state of the resource and serves as a guide for fisheries management. Reference points are used to define acceptable levels of mortality and recruitment criteria for fish populations. See the Glossary of Common Fisheries Terms (Internet Guide to International Fisheries Law, undated), available at <http://www.intfish.net/glossary/index.htm>.

${ }^{97}$ The fishery mortality limit reference was Fref $=0.26$. See Guidance Document 2006/01, n. 82 above, at 3.

${ }^{98}$ Fref $=0.25$; see ibid., at 5 . However, it should be noted that this harvest recommendation was subsequently amended to a risk-neutral combined TAC of $1250 \mathrm{mt}$ after being remanded back to the TMGC by the US NEFMC for further development. See Transboundary Management Guidance Committee, Guidance Document 2006/01 Addendum (Fisheries and Oceans Canada and NOAA Fisheries, November 2006), at 2, available at <http://www.mar.dfo-mpo.gc.ca/ science/tmgc/publications/GD2006_1A_E.pdf>

${ }^{99}$ For a review of progressions in regional seas agreements/ arrangements around the globe, see K. Wyman and J. Lin, 'Regional Seas', 15 Y.B. Int'l Env. L. (2004), 261. For a synopsis of how ecosystem approaches in particular are being implemented at the regional level around the globe and within regional fisheries management organizations, see Report of the Secretary-General on Oceans and the Law of the Sea (UN Doc. A/61/63, 9 March 2006), at 46-52.

${ }^{100}$ A. Chircop et al., 'The Gulf of Maine Agreement and Action Plan: A Novel but Nascent Approach to Transboundary Marine Environmental Protection', 19:4 Marine Pol'y (1995), 317.

${ }^{101}$ For a range of options for strengthening transboundary cooperation, including 'regional treaty formalization', see D.L. VanderZwaag, n. 89 above, at $282-285$.
}

๑) 2007 The Authors. Journal compilation @ 2007 Blackwell Publishing Ltd
Moving swiftly towards more formalized arrangements does not seem likely in light of 'missing ingredients'. Political interest and leadership supportive of negotiating a new ocean agreement or agreements is presently lacking. Champions of the cause have not stepped forward and been vocal.

Even if agreement could be reached on the need to strengthen regional transboundary cooperation in treaty form, difficult details would have to be sorted out. Those devilish details include, among others, the geographical scope of coverage; the breadth of ocean development and management issues to be addressed; incorporation of strong versus weak versions of sustainability principles; institutional structures; federal, State and provincial roles; advisory versus decision-making functions; relationships with existing organizations and programmes having interests or relevance to the Gulf of Maine; a financial mechanism or mechanisms; and dispute-resolution provisions.

While the voyage towards integrated ecosystem management arguably has a long way to go, Canada and the USA continue to steer their bows in the right direction. Good neighbourly ocean relations are being kept alive and incrementally progressing largely under the radar screen of informal arrangements.

Emily Pudden is a Researcher at the Marine \& Environmental Law Institute, Dalhousie University. She holds an LL.B. (Dalhousie), with certificates in Marine and Environmental Law, and Master's degrees in Marine Management (Dalhousie) and Archaeology (National University of Ireland, UCC).

David L. VanderZwaag is Professor of Law and Canada Research Chair in Ocean Law and Governance at the Marine \& Environmental Law Institute, Dalhousie Law School. He holds cross-appointments with the School for Resource and Environmental Studies and the International Development Studies Programme at Dalhousie and cochairs the International Union for Conservation of Nature and Natural Resource's Specialist Group on Oceans, Coasts and Coral Reefs.

This article is partly drawn from a 2006 report prepared for Fisheries and Oceans Canada by the Atlantic Coastal Zone Information Steering Committee Secretariat and the Marine and Environmental Law Institute, Dalhousie University, entitled 'Overview of Current Governance in the Bay of Fundy/Gulf of Maine: Transboundary Collaborative Arrangements and Initiatives'. The authors wish to acknowledge the research support of the Social Sciences and Humanities Research Council of Canada through a project entitled 'Strengthening Canada's Regional Fisheries Management Arrangements in Light of Sustainability Principles'. 